\title{
International Journal for Educational and Vocational Studies
}

\section{Teaching anti-discrimination attitudes through christian religious education in school}

\author{
Desi Sianipar*1, Wellem Sairwona ${ }^{1}$, Johanes Waldes Hasugian² ${ }^{2}$ Nova Ritonga ${ }^{3}$, \& Yunardi Kristian Zega1 \\ ${ }^{1}$ Department of Christian Religious Education, Universitas Kristen Indonesia, Jakarta, Indonesia \\ ${ }^{2}$ Department of Christian Religious Education, Sekolah Tinggi Teologi Sumatera Utara, Medan, Indonesia \\ ${ }^{3}$ Department of Christian Religious Education, Sekolah Tinggi Teologi Mawar Saron Lampung, Lampung, Indonesia \\ desi.sianipar@uki.ac.id; wellem.sairwona@uki.ac.id; johaneswhasugian@gmail.com ; novaritonga9@gmail.com; yunardichristian@gmail.com \\ *Corresponding Author: desi.sianipar@uki.ac.id | Phone Number: +6281578991962
}

\section{ARTICLE INFO}

Received: $12-05-2021$

Received in revised: 28-06-2021

Accepted: 27-07-2021

Available online: $30-8-2021$

\section{KEYWORDS}

Teaching anti; Discrimination; Discriminatory treatment;

Christian religious; Education

Curriculum; Learning model;

\section{A B S T R A C T}

This study aims to figure the implementation of anti-discrimination Christian Religious Education (CRE) at school and various things that can significantly shape students' anti-discrimination attitudes. By using descriptive qualitative methods, namely by adopting the research procedures of Miles and Habermas and support of other literature, the researchers found that CRE at schools has a strategic place in teaching anti-discrimination attitudes toward students. In this regard, the contextual and biblical CRE curriculum design and learning model presented in the class can lead students to have attitudes that do not discriminate against one another. Teaching anti-discrimination attitudes through CRE can be done simultaneously. CRE teachers lay the foundation or instill Christian values that differences are the reality and how students can accept and appreciate differences. Those are strengthened by the application of the CRE curriculum that contains the topic of anti-discrimination and synergized learning models in which students can interact, communicate and relate in different realities.

\section{INTRODUCTION}

Human Rights states that all human beings have freedom and equality in rights and dignity, while the Seventh Article emphasizes equality before the law without any discrimination (Universal Declaration of Human Rights (UDHR) 1948, 2015). However, acts of discrimination are still prevailing in various parts of the world. Discrimination is any form of unfair action based on a person's religion, race, gender, etc. Thereby violation of the principle of equality of human rights and freedoms ("The Right to Equality and Non-Discrimination in The Administration of Justice," 2003). Discriminatory actions are still quite strong in American schools, especially against people of color (Edwards, 2020). As in Germany, these actions also happen, especially for immigrants (Adair, 2015).

Discrimination practices also happen in education in Indonesia even though there are legal guarantees in this regard. For example, Law 20/2003, Law 35/2014, Regulation of the Minister of Education and Culture $82 / 2015$. Based on the annual report of the Indonesian Child Protection Commission (KPAI) in 2020, there were 6,519 complaints of cases of violations of children's rights, with the second-highest cluster in the world of education as many as 1,567 cases (Press Release 2020 Performance Report "Child Protection in the Era of the COVID-19 Pandemic", 2021). (Listanti et al., 2017) founds that the factors causing discrimination against students in primary schools include ethnic, social differences, the power of strong and weak groups, and physical limitations. (Rizki \& Djufri, 2020) found that many discrimination actions at schools because of them by the ineffective Bhineka Tunggal Ika learning.

In the context of Christian Religious Education (CRE) learning in schools, researchers surveyed 38 Christian teachers in Jakarta, Bogor, Depok, Tangerang, and Bekasi, namely: 16 elementary school teachers, 15 junior high school teachers, and 7 high school teachers. Based on the survey result, information was obtained that $47.1 \%$ of 38 teachers stated that Christian students also discriminated against other students. The most common types of discrimination are ostracizing friends with low grades, insulting other people's religion, degrading people based on their race/ethnicity, degrading people based on economic 
status, degrading people based on physicality, so on. In answering the question about the availability of antidiscrimination materials in CRE learning, most teachers $(71.1 \%)$ said that there were materials on antidiscrimination in Pendidikan Agama Kristen and Budi Pekerti (Christian Religious Education and Character) subject. Meanwhile, 28.9\% of teachers answered that there was no material on anti-discrimination. These answers indicate that they may not understand the meaning of antidiscrimination education. Furthermore, most activities that have been carried out to overcome acts of discrimination in schools are advising students not to be discriminatory, strengthening anti-discrimination attitudes through teaching materials, making anti-discrimination attitudes development activities, and involving students in interfaith activities in the community. However, serious efforts must be made by schools to reduce such acts of discrimination.

To overcome and anticipate discriminatory acts in schools, the government and the community need to make efforts simultaneously by implementing multicultural education, inclusive education, and intercultural education (Amin Miftakhul et al., 2020) (Umar \& Tumiwa, 2020). There are several studies regarding efforts to teach antidiscrimination attitudes in schools. Abadi and Muthohirin recommend the elimination of discriminatory attitudes through Islamic Religious Education strategies by emphasizing internalization, actualization, and application of human values based on values of the Qur'an by using the interpretation model of the Al-Qur'an text. The Qur'an was oriented towards progressivity and open-mindedness (Abadi \& Muthohirin, 2020). (Zhang \& Wu, 2017) introduce anti-discrimination education with a causal modelingbased approach, namely: direct/indirect discrimination and system/group/individual discrimination. (Howarth \& Andreouli, 2015) suggested that anti-discrimination education in the UK context addresses discrimination by considering the socio-political context, the local community context, and the school context from the perspective of social theory. (Suardana, 2020) provides a basis for a reason to implement multicultural $\mathrm{CRE}$ in Indonesia but does not specifically reach or discuss, for example, a person's physical or mental differences. Therefore, it is necessary to conduct more in-depth research on teaching anti-discrimination attitudes in CRE learning in schools. This study aims to provide an overview of the implementation of anti-discrimination CRE in schools and various things that can significantly shape students' antidiscriminatory attitudes.

\section{METHODS}

This research was conducted using qualitative methods with data collection techniques by reviewing the various research literature related to anti-discriminatory education and Christian education thought. Furthermore, data analysis was carried out using the Miles and Huberman model analysis technique which consisted of data reduction, data presentation, and conclusions. According to Sugiyono as quoted by Nuning Indah Pratiwi, data reduction is summarizing, choosing the main things, focusing on the important things, looking for themes and patterns. Presentation of data is done in the form of descriptions and relationships among categories. The conclusion is the answer to the research problem (Pratiwi, 2017). In this study, researchers focused on the theme of anti-discriminatory Christian religious education and presented related themes in it, including the philosophical and biblical foundations of Christian education in teaching anti-discrimination to students, developing an antidiscrimination CRE curriculum, and designing and implementing CRE learning models in schools. These things have interacted in the discussion so that the topics of discussion with each other have a relationship that describes the implementation of anti-discrimination CRE in schools. In the end, the researchers conclude to answer the research problem.

\section{RESULTS AND DISCUSSIONS}

Based on the research conducted, it was found that first, CRE has a strategic function in teaching anti-discriminatory attitudes to children in schools; second, the antidiscrimination curriculum is accommodated at every level of education, both Elementary School, Junior High School, and Senior High School; third, contextual and biblical CRE learning models play an important role in teaching antidiscriminatory attitudes in schools. These three findings were discussed below.

\section{Christian Religious Education as a Vehicle for Sowing Anti-Discrimination Attitudes}

In instilling these values, teachers need to base their teaching on the teaching model of Jesus Christ. Jesus received and communicated with the woman at Jacob's well, the woman caught in adultery. In addition, the Bible also tells about the Samaritan who loved regardless of identity differences and the Syro-Phoenician woman who showed an attitude of acceptance towards the weak. The teacher tells the children that their task is to imitate the attitude of the Lord Jesus and the Bible story. Thus, children have life references that direct them to appreciate and respect the reality of other children's differences (Tuju et al., 2021). The best atmosphere to provide religious education is when there is openness and trust, and free to learn. Usually, the best work in religious education is done when a learning community is created where people feel accepted, valued, and trusted. An atmosphere of trust arises when group members feel free to express themselves and their opinions without fear of ridicule or rejection (Hill, 1988). 


\section{Building an Anti-Discrimination Attitude in CRE Learning}

Humans are the handiwork of God, in His likeness and image (Gen. 1:26-27), and each has its uniqueness skin color, eyes, hair, face shape, body posture, language, way of thinking, so on. God loves all of His creation. His love is shown through his work of atonement for humans regardless of appearance (John 3:16; 1 John 2:2; Rom. 6:23; Deut. 10:17; Acts 10:34; Rom. 2: 11; Eph. 6:9). As God has loved sinners, the same love should also manifest in the association of one another. By understanding that there should be no discrimination against anyone by insulting, ostracizing, or treating other people in ways that can hurt their hearts. The Bible explains that what happens to others has been done to God (Matt. 25:31-46).

(S.Widiyono, 2018) offers several anticipatory efforts that can be done regarding discriminatory attitudes in the school environment, including respecting religious differences, fostering a critical understanding of social differences, building anti-ethnic discrimination attitudes, respecting language differences, building gender equality, respecting differences in ability and age. It is necessary to have a good understanding of teachers in responding to discriminatory actions that happen in schools. Not only that, but teachers also should practice their understanding with real examples to students by upholding the equality of students' rights and freedoms in the classroom. To anticipate discriminatory actions in schools, especially for children with special needs in Indonesia, (Hasugian et al., 2019) suggested an inclusive approach in schools. (Radhakrishnan, 2015) explained that teacher could like or dislike his/her students because of the differences, but he/she must be able to build positive motivation and trust in responding to these differences.

There are several efforts to build an anti-discrimination attitude in CRE learning in schools, including first, because God is very against all forms of violence, an attitude of rejection of violence must be carried out (Ps. 11:5). Several Bible verses can be referred to teach to love one another, including 1 Corinthians 13:13, 1 Peter. 3:8, John 15:12-13, Ephesians 4:2, Psalm 136:1, Romans 12:10, Deuteronomy 6:5. Second, recognize ethnic and linguistic differences. Teachers need to teach that God created humans in the likeness and image of Him (Gen. 1:26-27), which has its characteristics, both ethnicity, and language. Therefore, there should be no discrimination based on these differences. Third, mutual respect for differences in social status. Teachers need to teach that in God's eyes all humans are equal, poor or rich (Prov. 22:2). Therefore, there should be no discrimination based on social status. Fourth, build gender equality. Teachers need to explain that there is no particular gender that is superior and inferior because both men and women are created equal (Gen. 2:18). Fifth, explain that God created every human being with different abilities (Matt. 25:15). Therefore, teachers need to encourage their students to develop their abilities, so that no one feels inferior or humiliated. Sixth, set an example in giving honor (Eph. 6:1-9, 1 Pet. 5:5, 1 Tim. 4:12, Prov. 1:8-9, Col. 3:20).

\section{Developing an Anti-Discrimination-Based CRE Curriculum}

CRE in schools is a means for teachers to instill faith, Christian values, including anti-discrimination attitudes to students. The CRE curriculum is used as a guide for the implementation of CRE learning. The CRE curriculum is developed with various considerations to meet the needs of students and aims to equip them to practice antidiscriminatory attitudes and live together in diversity in society. Anti-discrimination materials can be found in the CRE curriculum.

Education and Culture, several materials discuss antidiscrimination education. Class I includes Lesson 10 (I am grateful for friends and teachers), Lesson 11 (I love and help friends), Lesson 12 (Living Together). Class II includes Lesson 8 (Getting Together with Neighbors), Lesson 9 (Getting Together at School). Class III includes Lesson 8 (I Need Other People), Lesson 9 (I Can Love Others), Lesson 10 (Learn To Love Like God), Lesson 11 (Grateful In Difference), Lesson 12 (I Want To Help Even If Different), Lesson 13 (You and I Are Equal Before God), Lesson 14 (Friendship with Everyone). Class IV includes Lesson 2 (God Is Present in Human Life). Class V includes Lesson 13 (Be a Blessing to Your Neighbor). Class VI includes Lesson 14 (Serving the Community). Class VII includes Chapter VII (Christian Values Become My Life Guide), Chapter IX (Solider towards Friends and Friends), Chapter X (Building Social Solidarity: Learning from the Teachings of Jesus Christ), Chapter XI (Building Solidarity in a Plural Society), Chapter XII (Conscience: Choosing the Right).

Class VIII includes Chapter VI (My Example Jesus). Class IX includes Chapter IX (Tolerance is a Part of My Life), Chapter X (Building Peace, Cultivating Tolerance), Chapter XI (Developing Myself for Service to Others), Chapter XII (A Meaningful Life for the School Environment), Chapter XIII (My Role in Community Development), Chapter XIV (Youth in a Changing World). Class X includes Chapter IV (Loving and Bringing Change), Chapter VIII (God's Work in Diversity), Chapter XI (Race, Ethnicity, and Gender), Chapter XIV (Christian Youth as Pioneers of Reform). Class XI includes an Explanation of Chapter VII (Justice and Peace in the Family), an Explanation of Chapter XII (Christian Families Become Blessings for the Environment). Class XII includes Chapter 1 (Democracy \& Human Rights), Chapter 2 (Practice of Democracy \& Human Rights), Chapter 3 (Democracy \& Human Rights in a Biblical Perspective), Chapter 5 (Multiculturalism), Chapter 6 (The Church and 
Multiculturalism), Chapter 7 (Living Together with People of Different Faiths), Chapter 10 (Implementing Justice for All Humans), and Chapter 13 (Being Doers of Love and Peace). Based on the materials above, there are many materials used by CRE teachers in teaching antidiscrimination in schools, starting from Class I (Elementary level) to Class XII (Senior High School). However, the distribution of the material looks irregular as for Class IV, Class V, and VI it only contains one material while in other classes it is quite adequate.

The quality of learning lies not only in the material but also in skills (Lumban Tobing, 2020). Teachers must be able to develop learning materials. Teachers must pay attention to student abilities, facilities, and infrastructure. If the CRE material is not appropriate due to various considerations, the teacher can design more appropriate material according to the context. In this case, the teacher's competence is needed to use the material.

The implementation of the curriculum in teaching an anti-discrimination attitude in CRE learning has a very strategic function. Therefore, CRE teachers need to realize and understand the potential in the CRE curriculum. The materials clearly illustrated that Christianity teaches love, togetherness, human rights, and so on. Christianity teaches that Christians should not discriminate against people, and behave unfairly to others as stated in Galatians 3:28.

\section{Implementing an Anti-Discriminatory CRE Learning Model}

The anti-discriminatory attitude of students can be formed in and through christian religious education. Therefore, education that is built should have a model that is designed in such a way. The design of the learning model relates to comprehensive learning achievement - cognitive, affective, and psychomotor. Learning behavior is a result of learning in the form of an understanding of the image of oneself and others, the value of a meaningful life, and life skills that are constantly honed. In teaching anti-discriminatory attitudes, CRE teachers need to develop relevant and Bible-oriented learning models. The Bible shares stories about loving one's neighbor, respecting and honoring different peoples, welcoming different groups socially. In particular, the Bible states how the teachings of Jesus are open to all regardless of the identity and background of listeners or those who follow Him. Jesus' model of imitating learning asked the scribes to answer from another's perspective about who one's neighbor is (Luk. 10:25-37). Another story is when Jesus paid special attention to a rich tax collector, Zacchaeus, even accidentally stopping by and eating at his house (Luk. 19:1-10).

This learning pattern inspires CRE teachers to create learning models within the framework of developing students' anti-discriminatory attitudes. This kind of model allows for acceptance and appreciation between teachers and students, and among students. In the atmosphere of openness, there is a discussion in which students can communicate, understand and appreciate the different views of other students. Student involvement in learning is an opportunity for students to have a meaningful learning experience. Students are not only involved in the classroom, but the teacher also can direct and guide students to learn by collecting information directly from their interaction with the community. For example, conducting observations and investigations about certain phenomena. It is undeniable that challenges faced by CRE teachers in the classroom, namely how to accommodate all the needs or interests of students. Teachers are faced with students who have different backgrounds (cultural, social, economic, physical, and psychological) and levels of intellectual abilities, as well as varied characters. When the teacher deals with children with special needs, they can show attention and loving touch, so that students can talk about it in their style. Thus, in implementing the anti-discriminatory CRE learning model, the multicultural (Banks, 2013), intercultural (Coulby, 2006), and inclusive (Connor et al, 2008) approach should encourage or become a strong foundation in it.

\section{CONCLUSIONS}

Discriminatory actions among students often happen as a variety of motives. Pedagogical efforts through CRE learning are a joint effort to form students' anti-discriminatory attitudes. The character of knowing and understanding the reality of students' differences taught to students, loving other students of various backgrounds, races, cultures, mental, physical, social, economic, and intellectual abilities. Those are an illustration that students have antidiscrimination values embedded in them. It shows that antidiscrimination CRE has been taught and received attention in schools. Because CRE in schools has a strategic function in teaching anti-discrimination attitudes in schools, various efforts must always be supported and done professionally by CRE teachers as education managers in schools. The development of a relevant CRE curriculum and the design and application of contextual and biblical CRE learning models are things that CRE teachers can do in responding to the challenges of discrimination today.

\section{Research Contributions}

Scientifically, this research builds a treasure trove of thinking about anti-discrimination CRE which is useful for forming anti-discrimination attitudes or actions in students at school. Practically, this research helps CRE teachers in teaching anti-discrimination attitudes in schools, especially in the design and implementation of the CRE curriculum as well as contextual and biblical learning models. 


\section{Acknowledgement}

The authors would like to thank all those who have helped in completing this research.

\section{Conflict of Interest}

The authors declare that they have no competing interests.

\section{REFERENCES}

Abadi, M., \& Muthohirin, N. (2020). Metode Cultural Responsive Teaching dalam Pendidikan Agama Islam: Studi Kasus Tindak Xenophobia dan Rasisme di Tengah Bencana Covid-19. Progresiva : Jurnal Pemikiran Dan Pendidikan Islam, 9(1), 34.

https://doi.org/10.22219/progresiva.v9i1.12520

Adair, J. K. (2015). The Impact of Discrimination on The Early Schooling Experiences of Children From Immigrant Families. Migration Policy Institute.

Amin Miftakhul, Harmanto, H., \& Sunarto, S. (2020). Impact Multicultural Education: Case study in Social Studies Learning. International Journal for Educational and Vocational Studies, 2(5). https://doi.org/10.29103/ijevs.v2i5.2500

Banks, J. A. (2013). The Construction and Historical Development of Multicultural Education, 1962-2012. Theory Into Practice, 52(sup1), 73-82.

https://doi.org/10.1080/00405841.2013.795444

Connor, D. J., Gabel, S. L., Gallagher, D. J., \& Morton, M. (2008). Disability studies and inclusive education implications for theory, research, and practice. International Journal of Inclusive Education, 12(5-6), 441-457.

https://doi.org/10.1080/13603110802377482

Coulby, D. (2006). Intercultural education: theory and practice. Intercultural Education, 17(3), 245-257. https://doi.org/10.1080/14675980600840274

Edwards, T. K. (2020). From the Editorial Board: Tangled Discrimination in Schools: Binding Hair to Control Student Identity. The High School Journal, 103(2), 53-56. https://doi.org/10.1353/hsj.2020.0006

Hasugian, J. W., Gaurifa, S., Warella, S. B., Kelelufna, J. H., \& Waas, J. (2019). Education for Children With Special Needs in Indonesia. 1st International Conference on Advance and Scientific Innovation (ICASI), Journal of Physics: Conference Series 1175, 4.

Hill, B. R. (1988). Key Dimensions of Religious Education. Saint Mary's Press.

Howarth, C., \& Andreouli, E. (2015). 'Changing the context': Tackling discrimination at school and in society. International Journal of Educational Development, 41, 184191. https://doi.org/10.1016/j.ijedudev.2014.06.004

Listanti, A., Harmianto, S., \& Sriyanto. (2017). Analyzing Students' Discrimination in Primary School. Jurnal Sains Sosial Dan Humaniora, 1(1), 3-14. https://doi.org/10.30595/jssh.v1i1.1034
Lumban Tobing, N. (2020). Kurikulum Pendidikan Agama Kristen di Indonesia. Mitra Sriwijaya: Jurnal Teologi Dan Pendidikan Kristen, 1(1), 77-108. https://doi.org/10.46974/ms.v1i1.8

Pratiwi, N. I. (2017). Penggunaan Media Video Call dalam Teknologi Komunikasi. Jurnal Ilmiah Dinamika Sosial, 1(2), 202-224. https://doi.org/10.38043/jids.v1i2.219

Radhakrishnan, S. R. (2015). Building Trust And Motivation In Students. Sai Om Journal of Arts \& Education, 2(1), 17-19. https://doi.org/10.1.1.836.9158

Rizki, A. M., \& Djufri, R. A. (2020). Pengaruh Efektivitas Pembelajaran Bhineka Tunggal Ika Terhadap Angka Rasisme dan Diskriminasi di Indonesia 2019. Vidya Samhita Jurnal Penelitian Agama, 6(1), 19-31.

S.Widiyono. (2018). Peran Guru dalam Mengimplementasikan Pendidikan Multikultural. Elementary School: Jurnal Pendidikan Dan Pembelajaran Ke-SD-An, 5(2), 282-290. https://doi.org/10.31316/esjurnal.v5i2.307

Siaran Pers Laporan Kinerja Tahun 2020 "Perlindungan Anak di Era Pandemi COVID-19." (2021).

https://www.kpai.go.id/informasipublik/pengumuman/siaran-pers-laporan-kinerja-tahun2020-komisi-perlindungan-anak-indonesia-perlindungananak-di-era-pandemi-covid-19

Suardana, I. M. (2020). Mengurai Landasan Konseptual Pendidikan Agama Kristen Multikultural dalam konteks Indonesia. Kurios: Jurnal Teologi Dan Pendidikan Agama Kristen, 6(1), 346-366.

https://doi.org/https://doi.org/10.30995/kur.v6i2.150

The Right to Equality and Non-Discrimination in The Administration of Justice. (2003). In Professional Training Series No. 9 Human Rights in The Administration of Justice: A Manual on Human Rights for Judges, Prosecutors and Lawyer (pp. 633-634). United Nations.

Tuju, S., Siahaan, H. E. R., Ayok, M., Siagian, F., \& Sampaleng, D. (2021). Hospitalitas Pendidikan Kristiani dalam Masyarakat Majemuk. Jurnal Teologi Berita Hidup, 3(2), 328-339. https://doi.org/10.38189/jtbh.v3i2.99

Umar, M., \& Tumiwa, J. F. (2020). Internalization of Multicultural Values through the Education Process in Manado State University. International Journal for Educational and Vocational Studies, 2(8), 720-725. https://doi.org/10.29103/ijevs.v2i8.2688

Universal Declaration of Human Rights (UDHR) 1948. (2015). United Nations.

https://www.un.org/en/udhrbook/pdf/udhr_booklet_en_web.pdf

Zhang, L., \& Wu, X. (2017). Anti-discrimination learning: a causal modeling-based framework. International Journal of Data Science and Analytics, 4(1), 1-16. 